\title{
Incidence of Listeria monocytogenes in different food products commercialized in Portugal
}

\author{
Cristina Mena $^{\mathrm{a}}$, Gonçalo Almeida ${ }^{\mathrm{a}}$, Luísa Carneiro ${ }^{\mathrm{a}}$, Paula Teixeira ${ }^{\mathrm{a}, *}$, \\ Tim $\operatorname{Hogg}^{\mathrm{a}}$, Paul A. Gibbs ${ }^{\mathrm{a}, \mathrm{b}}$ \\ ${ }^{a}$ Escola Superior de Biotecnologia, R. Dr. António Bernardino de Almeida, 4200-072 Porto, Portugal \\ ${ }^{\mathrm{b}}$ Leatherhead Food International, Surrey, UK
}

\begin{abstract}
Several types of food products on sale in Portugal, were examined for the presence of Listeria monocytogenes. Secondary enrichments, in Fraser broth, were analysed by the mini-Vidas LMO, enzyme-linked fluorescent immunoassay technique. Positive samples were confirmed by isolation on Oxford and PALCAM selective agars followed by biochemical characterization. Of 1035 samples, $72(7.0 \%)$ were positive for L. monocytogenes, the majority being from raw products (milk, meat, fish, flour) although some heat-processed or fermented foods (ready-to-eat) were also positive. In Portugal, a predilection for fresh cheese was indicated as a potential risk for consumers.
\end{abstract}

Keywords: Listeria monocytogenes; Incidence in foods

\section{Introduction}

Listeriosis is a severe infection caused by Listeria monocytogenes particularly among the elderly, very young and immunocompromized individuals and has also been associated with late-term miscarriages in pregnant women. The generalized infection known as listeriosis, when it occurs, normally follows the oral ingestion of the causative agent (Finlay, 2001). Whereas L. monocytogenes was recognized as an animal pathogen more than 70 years ago (Murray et al., 1926), it has been regarded as a significant foodborne pathogen only in more recent years. An outbreak in California during 1985, involving 142 cases with 48 deaths, was probably the final alert to the role of food in disseminating listeriosis (ICMSF, 1996). Since then it has been implicated in various food-associated outbreaks (McLauchlin, 1996). Important characteristics of $L$. monocytogenes contributing to foodborne transmission, are the ability to grow at refrigeration temperatures and in environments of reduced water-activity, measures

\footnotetext{
*Corresponding author. Tel.: +351-22-5580095; fax: +351-225580088.

E-mail address: paula@esb.ucp.pt (P. Teixeira).
}

commonly used to control the growth of pathogens in foods.

While the incidence of human listeriosis is low (2-15 per million), the death rate (deaths/number of cases) is greater than 20\% (Cabanes et al., 2002). In the United States, it is estimated that about 2500 cases of listeriosis occur each year, resulting in 500 deaths (Mead et al., 1999). The incidence of listeriosis showed a global increase in Europe and North America during the 1980s; however, it is not clear if this increase was real or if it was due to a better knowledge of the disease, improvements in diagnosis or better methods of detection and isolation of the organism. Foods implicated in outbreaks of listeriosis have included various types of products: dairy, meat, vegetables and seafood (Bell and Kyriakides, 1998; Schlech, 2000).

The high incidence of $L$. monocytogenes in foods (Farber and Peterkin, 1991; Jørgensen and Huss, 1998) and the high fatality rate associated with listeriosis, has contributed to L. monocytogenes being considered a public health hazard and a continuing source of loss to food processors due to the large number of voluntary and obligatory recalls, particularly in the US and Canada (http://www.safetyalerts.com, 2002). 
The eating habits of the population of Portugal are probably not so different to those of other southern European countries. Aside from standard western foods a significant variety of locally produced delicatessen meat products and traditional goat and sheep cheeses are consumed. Fish is a major part of the Portuguese diet. The real situation regarding listeriosis in Portugal is unknown, and little data exist on the prevalence of L. monocytogenes in foods consumed in the country (Vaz-Velho et al., 2000; Guerra et al., 2001). According to data published by the World Health Organization, there were no outbreaks or cases associated with this organism in the period 1993-1998 (WHO, 2001). However, it is important to note that listeriosis is not a reportable disease in Portugal (Anonymous, 1998).

The work presented here was an initial evaluation of the incidence of $L$. monocytogenes in certain commercial food products presented for sale on the Portuguese market contributing further exposure assessment data concerning the incidence of $L$. monocytogenes in for-sale foodstuffs.

\section{Methods}

During the period January 2000-September 2001, 1035 samples of various commercial food products (Table 1) were obtained from Portuguese producers and retailers, and transported to the laboratory in portable, insulated cold-boxes. Fresh meat and fresh fish samples were analysed on the day they were collected. The other samples were refrigerated and analysed 1-5 days after collection, but always before the best-before date. All samples were analysed using the mini-VIDAS LMO (hereafter referred to as mini-VIDAS) method. This is an enzyme-linked fluorescent immunoassay performed in the automated mini-VIDAS instrument, using antibody specific for L. monocytogenes. This method was employed as a current quality control method (Anonymous, 1996) allowing a high throughput and relatively rapid response time.

Food samples $(25 \mathrm{~g})$ were placed in $225 \mathrm{ml}$ Fraser broth (Biokar Diagnostics, Beauvais, France) or $225 \mathrm{ml}$ half-Fraser broth for dairy products, homogenized in a Stomacher for $2 \mathrm{~min}$, and incubated at $30^{\circ} \mathrm{C}$ for $24 \mathrm{~h}$. Aliquots $(1 \mathrm{ml}$ or $0.1 \mathrm{ml}$ for dairy products) of these primary enrichments were transferred to $10 \mathrm{ml}$ of secondary enrichment, Fraser broth, and incubated at $30^{\circ} \mathrm{C}$ for $24 \mathrm{~h}$. The sample wells of mini-VIDAS LMO reagent strips were inoculated with $0.5 \mathrm{ml}$ of each secondary enrichment broth. The results were obtained automatically after $70 \mathrm{~min}$. Enrichment broths were stored at $2-8^{\circ} \mathrm{C}$ and, when samples were positive in the mini-VIDAS (Test value $\geqslant 0.05$ ), were streaked on Oxford Agar and PALCAM Agar (Merck, Darmstadt, Germany) and incubated at $37^{\circ} \mathrm{C}$ for $48 \mathrm{~h}$. Five typical
Table 1

Incidence of $L$. monocytogenes in different food products

\begin{tabular}{|c|c|c|c|}
\hline Sample type & $\begin{array}{l}\text { Number of } \\
\text { samples }\end{array}$ & $\begin{array}{l}\text { Positive } \\
\text { samples }\end{array}$ & $\begin{array}{l}\text { Incidence } \\
(\%)\end{array}$ \\
\hline Frozen sliced courgette & 106 & 18 & 17.0 \\
\hline Frozen broccoli & 37 & 6 & 16.2 \\
\hline Frozen aubergine & 37 & 0 & - \\
\hline $\begin{array}{l}\text { Frozen sliced green } \\
\text { peppers }\end{array}$ & 31 & 7 & 22.6 \\
\hline Frozen peas & 27 & 4 & 14.8 \\
\hline $\begin{array}{l}\text { Frozen sliced red } \\
\text { peppers }\end{array}$ & 33 & 0 & - \\
\hline Raw milk & 6 & 1 & 16.7 \\
\hline Pasteurized milk & 28 & 0 & - \\
\hline $\begin{array}{l}\text { Cheese made from } \\
\text { pasteurized milk }\end{array}$ & 371 & 6 & 1.6 \\
\hline $\begin{array}{l}\text { Fresh cheese } \\
\text { ('queijo fresco') }\end{array}$ & 50 & 2 & 4.0 \\
\hline Raw chicken (muscle) & 15 & 9 & 60 \\
\hline Raw (red) meat & 17 & 3 & 17.7 \\
\hline Ham & 4 & 1 & 25 \\
\hline $\begin{array}{l}\text { Dry cured ham } \\
\text { ('presunto') }\end{array}$ & 44 & 1 & 2.3 \\
\hline Spanish-style sausage & 27 & 1 & 3.7 \\
\hline Smoked sausages & 48 & 0 & - \\
\hline Blood sausages & 9 & 1 & 11.1 \\
\hline Raw fish & 25 & 3 & 12.0 \\
\hline Shellfish & 8 & 0 & - \\
\hline Flour & 27 & 5 & 18.5 \\
\hline Pastry & 73 & $3^{\mathrm{a}}$ & 4.1 \\
\hline $\begin{array}{l}\text { Dried fruits (walnut, } \\
\text { hazelnut, pine-nut, } \\
\text { sultana, apricot) }\end{array}$ & 12 & 1 & 8.3 \\
\hline Total & 1035 & 72 & 7.0 \\
\hline
\end{tabular}

${ }^{\mathrm{a}}$ Of the 3 positive samples $1 / 3$ was from a chicken pie and $2 / 22$ from desserts with cream.

colonies per plate (when possible) were selected for confirmation by the tests of Gram reaction, catalase, oxidase, fermentation of the sugars mannitol $(0.5 \% \mathrm{w} / \mathrm{v})$, rhamnose $(1 \% \mathrm{w} / \mathrm{v})$ and xylose $(0.5 \% \mathrm{w} / \mathrm{v})$ and CAMP test with Staphylococcus aureus NCTC 1621 and Rhodococcus equi NCTC 25923.

\section{Results and discussion}

Table 1 describes the 1035 samples of various commercial food products that were analysed, the number of samples of each product analysed and the number of samples confirmed positive for L. monocytogenes.

The incidence of L. monocytogenes in raw meat, raw chicken, raw milk, raw fish, flour and frozen vegetables (Table 1), reflects the ubiquity of this organism, these products showing the highest incidence of the pathogen with $17.7 \%, 60 \%, 16.7 \%, 12 \%, 18.5 \%$ and $12.9 \%$ of samples positive, respectively. The presence of 
L. monocytogenes in these products cannot be considered as important as in ready-to-eat products since the raw products are normally cooked or pasteurized before consumption. It has been demonstrated that normal pasteurization processes are effective in the destruction of this pathogen so conventional cooking would also be expected to eliminate this organism (Nørrung, 2000). Hollywood et al. (1991) demonstrated that L. monocytogenes was not detected in minced beef cooked by conventional oven methods. The potential for ready-toeat products to be cross-contaminated must be recognized, however, either directly or via surfaces and equipment that may become contaminated with $L$. monocytogenes after being in contact with raw foods. Previous studies had also demonstrated that colonization of refrigerators by L. monocytogenes is a potential source of contamination of food products (Cox et al., 1989; Sergelidis et al., 1997).

These results demonstrate that post-processing contamination of food with $L$. monocytogenes persists in the production of ready-to-eat foods.

In relation to the delicatessen products, $3 \%$ of the 132 sampled were positive for $L$. monocytogenes. Positive samples included Spanish-style sausages $(3.7 \%)$, ham $(25 \%)$, blood sausage $(11.1 \%)$, and dry cured ham $(2.3 \%)$. Various sources of contamination of these products can be noted, including the raw material and post-processing contamination. The manufacturing processes involved may not assure the destruction of the pathogen, especially if the raw material is heavily contaminated, and as demonstrated in this study its prevalence is high in raw meat. The possibility of postprocessing contamination cannot be excluded, indeed studies in six delicatessen plants in France, identified cross-contamination between raw and cooked products and the inadequacy of cleaning and disinfecting procedures, as main sources of contamination (Salvat et al., 1995). This category of product has been the subject of recent major recalls due to L. monocytogenes contamination in the US (http://www.safetyalerts.com, 2002).

Different criteria or recommendations for admissible levels of $L$. monocytogenes in ready-to-eat products have been established in different countries, e.g. absence in $25 \mathrm{~g}$ of food in USA and Italy. However, a requirement for the absence of $L$. monocytogenes in some ready-toeat products is considered unrealistic by several countries (Nørrung, 2000). A tolerance of below $100 \mathrm{cfu} / \mathrm{g}$ of food at the time of consumption has been accepted in Germany, The Netherlands, France and the UK. This might present a serious problem to public health particularly in those products that support the growth of the organism. As referred to above, L. monocytogenes can grow at refrigeration temperatures and refrigeration is for some of these products, the only method used for the control of pathogenic organisms. Predictions effected using the Food MicroModel (Leatherhead Food International, Surrey, UK) software indicated that after 5 days (the shelf-life of fresh cheeses), of storage at $0-5^{\circ} \mathrm{C}$, the final concentration of $L$. monocytogenes would be $10^{3} / \mathrm{g}$ in a fresh cheese having an initial concentration of 10 cells per gram. This final concentration, however, would rise to $10^{7} \mathrm{cfu} / \mathrm{g}$ for a storage temperature of $10^{\circ} \mathrm{C}$.

The results presented here contribute further exposure assessment data concerning the incidence of L. monocytogenes in for-sale foodstuffs. Bearing in mind the recent Risk Assessments for L. monocytogenes in foods (Nørrung, 2000) it could be argued that there is a considerable risk to Portuguese consumers of contracting listeriosis from foods particularly those consumed without further heat treatment (pastries, dried fruits, cheeses and delicatessen foods). The predilection of the Portuguese consumer for fresh cheese ('queijo fresco') as a starter to a meal could pose a particular risk if not stored under correct refrigeration regimes. In 2001, 4500 tonnes of queijo fresco were produced for consumption in Portugal, approximately $10 \%$ of total cheese production (Anonymous, 2002).

\section{References}

Anonymous, 1996. VIDAS Listeria monocytogenes. AFNOR, Bio $12 / 3-03 / 96$.

Anonymous, 1998. Lista de doenças de declaração obrigatória a partir de 1 de Janeiro de 1999. Portaria 1071/98 de 31 Dezembro.

Anonymous, 2002. Anuário Food 2001. A.C. Nielsen, Lisboa.

Bell, C., Kyriakides, A., 1998. Listeria. A Practical Approach to the Organism and its Control in Foods. Blackie Academic \& Professional, London.

Cabanes, D., Dehoux, P., Dussurget, O., Frangeul, L., Cossart, P., 2002. Surface proteins and the pathogenic potential of Listeria monocytogenes. Trends Microbiol. 10, 238-245.

Cox, L.J., Kleiss, J., Cordier, J.L., Cordellana, C., Konkel, P., Pedrazzini, C., Benmer, R., Siebegna, A., 1989. Listeria spp. in food processing, non-food and domestic environments. Food Microbiol. 6, 49-61.

Farber, J.M., Peterkin, P.I., 1991. Listeria monocytogenes, a foodborne pathogen. Microbiol. Rev. 55, 476-511.

Finlay, B.B., 2001. Cracking Listeria's password. Science 292, $1665-1667$.

Guerra, M.M., Mclauchlin, J., Bernardo, F.A., 2001. Listeria in readyto-eat and unprocessed foods produced in Portugal. Food Microbiol. 18, 423-429.

Hollywood, N.W., Varabioff, Y., Mitchell, G.E., 1991. The effect of microwave and conventional cooking on the temperature profiles and microbial flora of minced beef. Int. J. Food Microbiol. 14, $67-75$.

ICMSF, 1996. Microorganisms in Foods 5. Characteristics of Microbial Pathogens Listeria monocytogenes. Blackie Academic \& Professional, London, pp. 141-182.

Jørgensen, L.V., Huss, H.H., 1998. Prevalence and growth of Listeria monocytogenes in naturally contaminated seafood. Int. J. Food Microbiol. 42, 127-132.

McLauchlin, J., 1996. The relationship between Listeria and listeriosis. Food Control 7, 187-193. 
Mead, P.S., Slutsker, L., Dietz, V., McCaig, L.F., Bresee, J.S., Shapiro, C., Griffin, P.M., Tauxe, V., 1999. Food-related illness and death in the United States. Emerg. Infect. Dis. 5, 607-625.

Murray, E.G.D., Webb, R.A., Swann, M.B.R., 1926. A disease of rabbits characterised by a large mononuclear leucocytosis, caused by a hitherto undescribed bacillus Bacterium monocytogenes (n.sp.). J. Pathol. Bacteriol. 29, 407-439.

Nørrung, B., 2000. Microbiological criteria for Listeria monocytogenes in foods under special consideration of risk assessment approaches. Int. J. Food Microbiol. 62, 217-221.

Salvat, G., Toquin, M.T., Michel, Y., Colin, P., 1995. Control of Listeria monocytogenes in delicatessen industries: the lessons of a listeriosis outbreak in France. Int. J. Food Microbiol. 25, 75-81.
Schlech, W.F., 2000. Foodborne listeriosis. Clin. Infect. Dis. 31, 770-775

Sergelidis, D., Abrahim, A., Sarimvei, A., Panoulis, C., Karaionnoglou, Pr., Genigeorgis, C., 1997. Temperature distribution and prevalence of Listeria spp. in domestic, retail and industrial refrigerators in Greece. Int. J. Food Microbiol. 34, 171-177.

Vaz-Velho, M., Duarte, G., Gibbs, P., 2000. Evaluation of miniVIDAS rapid test for detection of Listeria monocytogenes from production lines of fresh to cold-smoked fish. J. Microbiol. Methods 40, 147-151.

WHO, 2001. In: Tirado, C., Schmidt, K. (Eds.), WHO Surveillance Programme for Control of Foodborne Infections and Intoxications in Europe-7th report 1993-1998. Institute for Health Protection of Consumers and Veterinary Medicine, Berlin. 